\title{
Experiments on Tanier Production with Conservation in Puerto Rico's Mountain Region ${ }^{1}$
}

\author{
Fernando Abruña-Rodriguez, Elvin G. Boneta Garcia, \\ José Vicente-Chandler, and Servando Silva ${ }^{2}$
}

\section{INTRODUCTION}

Although taniers (Xanthosoma $s p$.) are a staple in the diet of millions of people throughout the Tropics, few experimental data are available on their cultural or fertility requirements. Gooding and Campbell ${ }^{3}$ in Trinidad found that pieces of the main rhizome produced higher yields than did tubers used as seed, and that the Barbados and Choubouton cultivars yielded best. In Puerto Rico, Barrett ${ }^{4}$ noted that taniers did not respond to commercial fertilizers, and that a $1 \frac{1}{2}-\mathrm{x} 3$-foot planting distance appeared best.

This paper summarizes the results of experiments on the cultural and fertility requirements of taniers growing on steep latosols in the Humid Mountains of Puerto Rico.

\section{MATERIALS AND METHODS}

The experiments were carried out at elevations ranging from 1,500 to 2,500 feet above sea level. Mean annual temperature was about $75^{\circ} \mathrm{F}$., with maximum variations ranging from $55^{\circ}$ to $85^{\circ} \mathrm{F}$. Annual rainfall was 55 inches at Orocovis, 65 at Adjuntas, and 80 at Jayuya. Rainfall was fairly well distributed except for a rather dry period from January through March.

The soils in which the various experiments were conducted were sampled and analyzed for bulk density, percentage of large pores, organic-matter content, $\mathrm{pH}$, exchange capacity, and exchangeable bases. In all cases the soils had been in unfertilized grasses or shaded coffee for the previous 10 years.

${ }^{1}$ This paper covers work carried out cooperatively between the Soil and Water Conservation Research Division, Agricultural Research Service, USDA, and the Agricultural Experiment Station of the University of Puerto Rico, Río Piedras, P.R.

${ }^{2}$ Soil Scientist, Soil and Water Conservation Research Division, Agricultural Research Service, USDA, stationed at Río Piedras, P.R.; Research Assistant at the Agricultural Experiment Station, University of Puerto Rico, stationed at Adjuntas, P.R.; Project Supervisor and Agricultural Technician, Soil and Water Conservation Research Division, Agricultural Research Service, USDA, stationed at Río Piedras, P.R.

${ }^{3}$ Gooding, H. J. and Campbell, J. S., Preliminary trials of West Indian Xanthosoma cultivars, Trop. Agr. 38(2): 145-52, 1961. 1905 .

${ }^{4}$ Barrett, O. W., The Taniers of Puerto Rico, P.R. Agr. Exp. Sta. Bull. 6, 27 pp., 
Except as noted, the general experimental procedure was as follows: All treatments were replicated 5 times in a randomized-block design with individual plots $1 / 300$ acre in size. The Morada variety of taniers was planted at $1 \frac{1}{2}-\times 3$-foot spacing, using pieces of the rhizome as seed. Five hundred pounds of 12-6-16 fertilizer were applied per acre 1 and 5 months after planting. The soil was limed to $\mathrm{pH} 6.0$ before planting and was treated to control soil insects. Nitrogen was applied as ammonium sulfate, phosphorus as 20-percent superphosphate, and potassium, as potassium chloride. Weeds were controlled by periodic light hoeing. Taniers were planted in the spring in undisturbed soil, and were harvested 11 months later.

SHADE TOLERANCE

This experiment was performed to determine the effect of light shade provided by trees compared with full sunlight on yields of taniers on a Los Guineos clay near Jayuya. All trees (Inga inga (L)) were removed from the unshaded plots, but sufficient trees were left in the shaded plots to provide about 50 -percent shade. Individual plots were $20 \times 60$ feet with 40 -foot borders between plots. Treatments were replicated 3 times.

\section{TILLAGE REQUIREMENTS}

Three experiments were carried out to compare the effect of complete land preparation $v s$. planting directly in undisturbed soil on yields of taniers on Múcara, Cialitos, and Catalina clay soils at Orocovis, Adjuntas, and Orocovis again, respectively. The tilled plots were thoroughly worked to a depth of 8 inches. Weeds were removed from the untilled plots by carefully scraping the soil surface with a hoe. Thereafter, weeds in all plots were controlled by light hoeing.

\section{HERBICIDES}

This experiment was performed also to determine the effect of three herbicides on growth of taniers and weeds on Cialitos clay at Orocovis. Four pounds per acre of the various herbicides were applied to the bare soil immediately after the taniers were planted.

\section{VARIETIES}

Two experiments were made to determine the yields of 12 tanier varieties or cultivars on Cialitos clay at Orocovis and on Alonso clay at Adjuntas.

PLANT POPULATION

Two experiments were made to determine the effect of different plant populations on yields of taniers on Cialitos clay at Orocovis and on Alonso clay at Adjuntas. 
Three experiments were made to determine the response of taniers to $\mathrm{N}, \mathrm{P}, \mathrm{K}$, and limestone applications on Cialitos, Los Guineos, and Alonso clay soils at Orocovis, Jayuya, and Adjuntas, respectively. Samples consisting of the blade of the third leaf from the central whorl of six plants in each plot were taken 4 months after planting, and were analyzed for $\mathrm{N}, \mathrm{P}, \mathrm{K}, \mathrm{Ca}, \mathrm{Mg}$, and $\mathrm{Mn}$.

\section{N-SOURCE}

One experiment was undertaken to determine the effect of six sources of nitrogen on yields of taniers growing on Catalina clay near Orocovis. A

TABLE 1-Characteristics of the surface 6 inches of soil at the various experimental sites in Puerto Rico

\begin{tabular}{|c|c|c|c|c|c|}
\hline Soil characteristics & $\begin{array}{c}\text { Catalina } \\
\text { clay } \\
\text { (Orocovis) }\end{array}$ & $\begin{array}{l}\text { Múcara } \\
\text { clay } \\
\text { (Orocovis) }\end{array}$ & $\begin{array}{c}\text { Cialitos } \\
\text { clay } \\
\text { (Adjuntas) }\end{array}$ & $\begin{array}{c}\text { Alonso } \\
\text { clay } \\
\text { (Adjuntas) }\end{array}$ & $\begin{array}{c}\text { Los Guineos } \\
\text { clay } \\
\text { (Jayuya) }\end{array}$ \\
\hline Bulk density............/cc. & 0.98 & 1.09 & 1.07 & 1.0 & 1.1 \\
\hline $\begin{array}{l}\text { Pores drained at } 1 / 3 \text {-atm. } \\
\text { pressure......... percent }\end{array}$ & 16.4 & 14.5 & 15.7 & 13.6 & 14.0 \\
\hline $\begin{array}{l}\text { Organic matter..... percent } \\
\text { Exchange capacity }\end{array}$ & 4.8 & 4.7 & 5.9 & 5.0 & 7.4 \\
\hline $\begin{array}{l}\text { meq./100 g. soil } \\
\text { Exchangeable bases }\end{array}$ & 14.5 & 20.0 & 17.9 & 14.3 & 24.5 \\
\hline meq./100 g. soil & 4.6 & 13.2 & 6.7 & 7.0 & 5.4 \\
\hline $\mathrm{pH} \ldots \ldots \ldots \ldots \ldots \ldots \ldots \ldots$ & 5.0 & 5.6 & 5.0 & 5.3 & 4.7 \\
\hline
\end{tabular}

total of 200 pounds of $\mathrm{N}$ per acre from the various sources was applied in three equal applications.

\section{RESULTS AND DISCUSSION}

\section{SOIL CHARACTERISTICS}

Characteristics of the various soils on which the experiments were carried out are summarized in table 1 . All soils have excellent physical condition, as evidenced by bulk densities averaging 1.05 with about 15 percent of the pores drained at $1 / 3 \mathrm{~atm}$. of pressure. The soils are acid and rather high in organic matter and exchange capacity.

\section{SHADE TOLERANCE}

The following tabulation shows that shade trees reduced yields of taniers to less than one-third of those produced in full sunlight. 


\begin{tabular}{ccc} 
& \multicolumn{2}{c}{$\begin{array}{c}\text { Yields of taniers (cwi. of } \\
\text { tubers/acre) }\end{array}$} \\
Replicate & Unshaded & Shaded \\
A & 131 & 24 \\
B & 125 & 30 \\
C & 78 & 35 \\
Average. ............... & 111.3 & \\
\hline
\end{tabular}

The sensitivity of taniers to shade indicates that they should be grown alone, or associated with a lower growing crop. The common practice of intercropping taniers with plantains or bananas thus appears to be questionable.

\section{TILLAGE REQUIREMENTS}

The following tabulation shows that just as high yields of taniers were produced on three soils without tillage as with complete land preparation. None of the apparent differences in yield was statistically significant.

\begin{tabular}{|c|c|c|}
\hline \multirow[b]{2}{*}{ Soil } & \multicolumn{2}{|c|}{$\begin{array}{c}\text { Yields of taniers (cwot. of } \\
\text { tubers/acre) }\end{array}$} \\
\hline & Tilled & Unilled \\
\hline Cialitos clay (Adjuntas) & 117 & 96 \\
\hline Catalina clay (Orocovis) & 67 & 74 \\
\hline Mucara clay (Orocovis) & 119 & 136 \\
\hline Average. & $\overline{101}$ & $\overline{102}$ \\
\hline
\end{tabular}

There is apparently no need to till these typical soils of the Humid Tropics, except for weed control. Planting directly in undisturbed soil with herbicide applications to control weeds can reduce erosion on steep lands and can increase labor efficiency while maintaining high yields (fig. 1).

\section{HERBICIDES}

The following tabulation shows the effect of four herbicides on growth of taniers and weeds determined by observation 7 weeks after application at planting.

$\begin{array}{lcc}\text { Herbicide } & \begin{array}{c}\text { Percentage of } \\ \text { Relative growth } \\ \text { of taniers }\end{array} & \begin{array}{c}\text { ground covered } \\ \text { by weeds }\end{array} \\ \text { None } & 8 & 42 \\ \text { Simazine } & 5 & 10 \\ \text { Amiben } & 9 & 11 \\ \text { Prometryne [2,4-bis (isopropylamine) } & 9 & 1 \\ \quad \text {-4 methyl mercapto-2-triazine] } & & \end{array}$

1 Trade names are used in this publication solely for the purpose of providing specific information. Mention of a trade name does not constitute a guarantee, warranty, or endorsement by the U.S. Department of Agriculture or the P.R. Agricultural Experiment Station over other similar products not mentioned. Use of these materials is experimental and registration must be obtained before they are used in the commercial production of taniers.

${ }^{2} 10=$ Optimum growth. 
Prometryne gave almost perfect weed control and had no effect on tanier growth. Amiben did not affect tanier growth and gave fairly good weed control, whereas Simazine was toxic to the taniers.

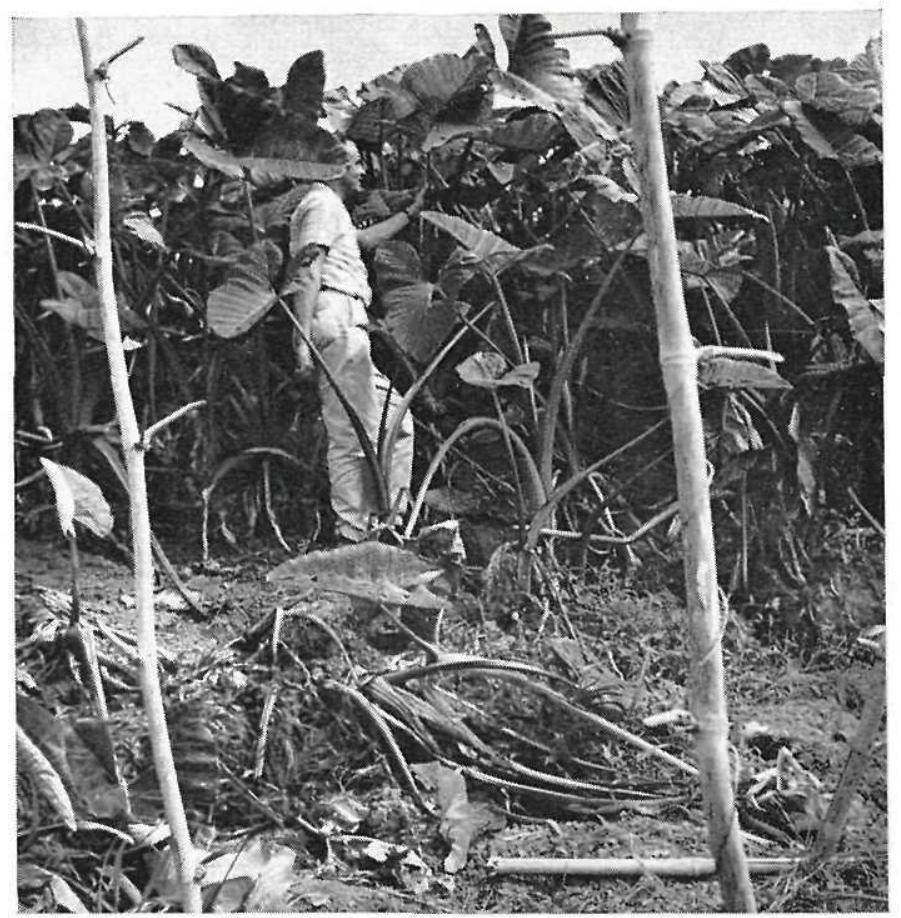

FIg. 1.-This field of intensively managed taniers on a typical latosol yielded 8 tons of tubers for human consumption and 9 tons of high-starch rhizomes suitable for animal consumption per acre.

\section{VARIETIES $^{5}$}

Table 2 shows that at Adjuntas, with high rainfall, the Morada, Viequera, Rascana, Drearies, Bisley, and Inglesa varieties or cultivars produced similar high yields in this order. During a drought year which limited yields at Orocovis, the Bisley, Rascana, and Viequera varieties or cultivars outyielded Kelly and Vinola. The Rascana variety outyielded the Bisley but not the Viequera variety.

\section{PLANT POPULATION}

Table 3 shows that plant population had no perceptible effect on yields of taniers at Adjuntas when weather was favorable. However, at Orocovis,

${ }^{5}$ Seed of these varieties or cultivars were provided by the Gurabo Substation of the Agricultural Experiment Station of the University of Puerto Rico. 
where yields were lower because of drought, tanier yields were 75-percent higher with 7,260 than with 4,840 plants per acre, and continued to increase with plant population up to 14,520 plants per acre.

\section{TABLE 2-Productivity (cwt./acre) of various tanier varieties} and cultivars at Orocovis and Adjuntas, P.R.

\begin{tabular}{|c|c|c|c|}
\hline \multirow{2}{*}{ Variety or cultivars } & \multicolumn{2}{|c|}{ Yields $^{1}$ of tubers at- } & \multirow{2}{*}{$\begin{array}{l}\text { Yields of rhizomes? } \\
\text { at Adjuntas }\end{array}$} \\
\hline & $\begin{array}{l}\text { Orocovis on } \\
\text { Cialitos clay }\end{array}$ & $\begin{array}{l}\text { Adjuntas on } \\
\text { Alonso clay }\end{array}$ & \\
\hline Morada & - & $142 \mathrm{a}$ & 120 \\
\hline Viequera & $82.2 \mathrm{a}, \mathrm{b}$ & $139 \mathrm{a}$ & 105 \\
\hline Rascana & $91.2 \mathrm{a}$ & $129 \mathrm{a}, \mathrm{b}$ & 75 \\
\hline Drearies & & $125 \mathrm{a}, \mathrm{b}, \mathrm{c}$ & 75 \\
\hline Bisley & $72.9 \mathrm{~b}$ & $117 \mathrm{a}, \mathrm{b}, \mathrm{c}, \mathrm{d}$ & 87 \\
\hline Inglesa & & $117 \mathrm{a}, \mathrm{b}, \mathrm{c}, \mathrm{d}$ & 93 \\
\hline Barbados & & 87 b,c,d,e & 54 \\
\hline Choubouton & & $84 \mathrm{c}, \mathrm{d}, \mathrm{e}$ & 63 \\
\hline Choramille & & $78 \mathrm{~d}, \mathrm{e}, \mathrm{f}$ & 66 \\
\hline Kelly & $51.2 \mathrm{c}$ & $51 \mathrm{e}, \mathrm{f}$ & 50 \\
\hline Dominicana & & $36 \mathrm{f}$ & 54 \\
\hline Vinola & $51.5 \mathrm{c}$ & - & - \\
\hline \multirow{2}{*}{ L.S.D. ${ }_{01}^{05}$} & 16.5 & 43.0 & \\
\hline & 22.5 & 58.5 & \\
\hline
\end{tabular}

1 Varieties having 1 or more letters in common do not differ significantly at the 05 level.

${ }^{2}$ Generally not used for human consumption, but often used for feeding pigs.

\section{FERTILIZER AND LIME RATES}

Table 4 shows that with all other nutrients present in abundance, taniers growing on Los Guineos clay at Jayuya and on Cialitos clay at Orocovis responded to the application of 100 pounds of $\mathrm{N}$ per acre, but did not respond to heavier applications of this nutrient. There was a strong indication of a response to 100 pounds of $\mathrm{N}$ per acre on Alonso clay at Adjuntas.

Taniers responded to the application of 80 pounds of $\mathrm{P}$ per acre on Cialitos clay at Orocovis, but did not respond to $\mathrm{P}$ fertilization on the other two soils.

Taniers responded to the application of 200 pounds of $K$ per acre on Cialitos clay at Orocovis, but did not respond to $\mathrm{K}$ fertilization on the other two soils.

Taniers did not respond to liming on Cialitos or Alonso soils, but responded negatively to the application of 8 tons of limestone per acre on acid ( $\mathrm{pH} 4.8$ ) Los Guineos clay at Jayuya. 
TABLE 3.-Effect of plant population on yields of taniers at Orocovis and Adjuntas, P.R.

\begin{tabular}{|c|c|c|c|c|}
\hline \multirow{3}{*}{ Plants per acre } & \multirow{3}{*}{ Planting distance } & \multicolumn{3}{|c|}{ Yields } \\
\hline & & \multirow{2}{*}{$\begin{array}{c}\text { Orocovis } \\
\text { tubers }\end{array}$} & \multicolumn{2}{|c|}{ Adjuntas } \\
\hline & & & Tubers & Rhizome \\
\hline & Feet & Cwt./acre & Cwt./acre & Cwot./acre \\
\hline 4,840 & $3 \times 3$ & 38.6 & 124 & 144 \\
\hline 7,260 & $2 \times 3$ & 67.7 & 125 & 138 \\
\hline 9,680 & $3 \times 1 \frac{1}{2}$ & 72.2 & 112 & 153 \\
\hline 10,890 & $2 \times 2$ & - & 134 & 162 \\
\hline 14,520 & $2 \times 1 \frac{1}{2}$ & - & 124 & 165 \\
\hline 9,680 & $2 \times 1 \frac{1}{2} \times 4$ & 75.9 & 126 & 165 \\
\hline 14,520 & $1 \times 3$ & 87.1 & - & - \\
\hline 7,260 & $4 \times 2 \times 2$ & 67.7 & 一 & - \\
\hline \multicolumn{2}{|c|}{ L.S.D. ${ }_{01}^{05}$} & $\begin{array}{l}17.8 \\
24.1\end{array}$ & N.S. & N.S. \\
\hline
\end{tabular}

TABLE 4.-Effect of fertilization and liming on yields of taniers on typical latosols at Orocovis, Jayuya, and Adjuntas, P.R.

\begin{tabular}{l|r|r|c|c|c|c|c}
\hline & \multicolumn{3}{|c|}{ Nutrients applied per acre } & \multicolumn{3}{c}{ Yields of tanier tubers } \\
\cline { 2 - 7 } $\begin{array}{c}\text { Treatment } \\
\text { No. }\end{array}$ & $\mathrm{N}$ & $\mathrm{P}$ & $\mathrm{K}$ & $\begin{array}{c}\text { Lime- } \\
\text { stone }\end{array}$ & $\begin{array}{c}\text { Cialitos } \\
\text { clay } \\
\text { (Orocovis) }\end{array}$ & $\begin{array}{c}\text { Los Guineos } \\
\text { clay } \\
\text { (Jayuya) }\end{array}$ & $\begin{array}{c}\text { Alonzo clay } \\
\text { (Adjuntas) }\end{array}$ \\
\hline & Lb. & Lb. & Lb. & Tons & Cwt./acre & Cwt./acre & Cwt./acre \\
1 & 200 & 80 & 400 & 4 & 36 & 120 & 148 \\
2 & 0 & 80 & 400 & 4 & 26 & 95 & 118 \\
3 & 100 & 80 & 400 & 4 & 43 & 127 & 143 \\
4 & 200 & 0 & 400 & 4 & 23 & 122 & 131 \\
5 & 200 & 40 & 400 & 4 & 28 & 104 & 137 \\
6 & 200 & 80 & 0 & 4 & 32 & 100 & 115 \\
7 & 200 & 80 & 200 & 4 & 44 & 119 & 115 \\
8 & 200 & 80 & 400 & 0 & 34 & 136 & 118 \\
9 & 200 & 80 & 400 & 8 & 43 & 97 & 131 \\
\hline \hline
\end{tabular}

A severe drought limited tanier yields at Orocovis, but high yields were obtained in the other two experiments.

The following tabulation indicates the dry-weight nutrient contents in young, mature leaf blades of 4-month-old taniers associated with high yields, and thus with a satisfactory nutritional status: 




$\mathrm{N}$ fertilization did not affect the $\mathrm{N}, \mathrm{P}, \mathrm{Ca}$, or Mn content of the tanier leaves, but slightly increased their $\mathrm{K}$ content, and decreased their $\mathrm{Mg}$ content. Lime, K, and P fertilization had no effect on composition of the tanier leaves, except that liming decreased their Mn content, which averaged 349, 250 and 184 p.p.m. when 0,4 , and 8 tons of limestone were applied per acre, respectively.

\section{N SOURCE}

The following tabulation shows the effect of various $\mathrm{N}$ sources on yields of taniers:

$N$ source

Ammonium sulfate

Sodium nitrate

Urea

Ammonium hydroxide

Ammonium nitrate

Ammonium-nitrate-lime
Yields of taniers (cwot. tubers/acre)

25.8

3.0

28.5

32.4

32.4

28.5

Taniers fertilized with sodium nitrate produced almost no yield and exhibited severe burning of the older leaves. All other sources were apparently equally effective providers of $\mathrm{N}$ to taniers even though overall yields were low because of severe drought.

\section{SUMMARY}

Experiments conducted on the cultural and fertility requirements of taniers (Xanthosoma sp.) on typical latosols in the Humid Mountain Region of Puerto Rico showed:

1. Taniers grown under 50-percent shade provided by trees yielded only a third as much as those grown in full sunlight.

2. Taniers planted directly in undisturbed latosols yielded as much as those planted in thoroughly prepared soil. Prometryne gave good results as a pre-emergence herbicide.

3. The Morada, Viequera, Rascana, Bisley, Drearies, and Inglesa varieties gave promising results.

4. Yields increased with population up to 14,700 plants per acre in one experiment, but were unaffected by plant population in another where more favorable rainfall resulted in higher yields. 
5. Taniers responded rather consistently to 100 pounds of $\mathrm{N}$ per acre in two equal applications but exhibited variable response to applications of $\mathrm{P}$ and $\mathrm{K}$. The application of 100 pounds $\mathrm{N}, 40$ pounds $\mathrm{P}$ (92 pounds $\mathrm{P}_{2} \mathrm{O}_{5}$ ), and 100 pounds $\mathrm{K}$ per acre would seem to be a reasonable practice.

6. Ammonium sulfate, urea, ammonium hydroxide, ammonium nitrate and ammonium-nitrate-lime were equally efficient providers of $\mathrm{N}$ to taniers, but sodium nitrate applications severely reduced yields.

\section{RESUMEN}

Los experimentos llevados a cabo para determinar los requisitos de la yautía (Xanthosoma sp.), sembrada en suelos "latosol" de la Región Montañosa Húmeda de Puerto Rico, en cuanto a su cultivo y abonamiento demostraron lo siguiente:

1. Los rendimientos se redujeron a un tercio cuando las siembras se hicieron bajo un 50 por ciento de sombra de árboles.

2. Cuando la siembra se hizo en terrenos sin preparar, los rendimientos fueron iguales a los que se obtuvieron de las siembras hechas en terreno arado. El prometryne fue eficiente como yerbicida pre-emergente en estas siembras de yautías.

3. Los rendimientos de las variedades Morada, Viequera, Rascana, Bisley, Drearies e Inglesa demostraron que estas variedades son prometedoras.

4. La producción en uno de los experimentos aumentó cuando se aumento el número de plantas por cuerda a 14,700 . Sin embargo, esto no ocurrió en otro experimentó que se sembró con igual número de plantas en una región con lluvia abundante y donde los rendimentos fueron mayores.

5. Hubo una reacción favorable de las yautías al abonamiento con 100 libras de nitrógeno por cuerda divididas en dos aplicaciones iguales en dos ocasiones. La reacción de las yautías a las aplicaciones de potasio y fósforo fue variable. $\mathrm{El}$ abonamiento con 100 libras de nitrógeno, 40 de fósforo (92 libras $\mathrm{P}_{2} \mathrm{O}_{5}$ ) y 100 de potasio por cuerda parece ser una práctica aconsejable.

6. El uso del nitrato sódico como fuente de nitrógeno fue desfavorable a la producción, mientras que el sulfato amónico, la urea, el nitrato amónico, el hidróxido de amoníaco y el nitrato amónico con cal, fueron igualmente adecuados para suplir el nitrógeno requerido por las yautías. 